\title{
THE STANDARD OF LIVING IN RURAL POPULATION OF POLAND
}

\author{
DOI: http://dx.doi.org/10.18509/GBP.2018.40
}

UDC: $330.59: 316.334 .55(438)$

\section{Patryk Brambert \\ Iwona Kiniorska \\ Ewa Palka-Lebek}

Institute of Geography, Department of Mathematics and Natural Sciences,

The Jan Kochanowski University in Kielce, Poland

\begin{abstract}
Polish rural areas face various social, economic and ecological problems. These processes greatly affect diversification of the standard of living in rural areas. The goal of the study was to assess spatial diversification of the standard of living in rural areas in Poland in 2013. In the analysis it was evaluated with Perkal's synthetic index, known also as the zscore index. Perkal's index was based on dozen objective descriptors concerning several life aspects. It referred to: demographics of young or able to work part of the population, housing conditions and the use of technical infrastructure, labour market, entrepreneurship and well-being of rural inhabitants. The highest standard of living was shown for rural gminas in the vicinity of urban agglomerations. The lowest standards of living were in typical rural areas with poorly developed services functions. These were mainly depopulated units located in the outskirts of NUTS 2 regions - voivodeships. The Vistula river marked the dividing line in the standards of living in rural areas of the country.
\end{abstract}

Keywords: rural gminas, standard of living, Perkal's synthetic index, Poland

\section{INTRODUCTION}

Economic - together with social development - is a result of changes in the economic area determined by many factors. Endogenous elements which may play a leading role include economic activity of inhabitants, advantages of the region and their use, the type of economy, the nature of demographic phenomena. The assessment of conditions of the standard of living of rural areas may be carried out by means of analysis of conditions and factors. The conditions are passive and poorly controllable in the short-term. Factors are active and more controllable and their implementation is necessary for restructuring and regional development [1]. Major conditions are: demographic situation, the structure of settlement network, natural environment with its resources, infrastructure and the type of economy.

The aim of the study was to assess spatial diversification of the standard of living in polish rural areas. The classification concerned 2013. It focused on all rural gminas as well as rural parts of urban-rural gminas - 2,257 administrative units in total (gminas as the lowest level of three-tier territorial division of the country). Perkal's synthetic index [2] was used with 12 variables:

1. Percentage of population at pre-working age (0-18 years),

2. Percentage of population at working age,

3. Deaths per 1,000 inhabitants, 
4. Natural increase per 1,000 population,

5. Net migration per 1,000 inhabitants,

6. Useful floor area of dwellings per capita,

7. Number of dwellings per 1,000 inhabitants,

8. Percentage of users of water supply network in the total population,

9. Percentage of users of sewage system in the total population,

10. Percentage of unemployed persons in the population at working age,

11. Entities per 1,000 inhabitants at working age,

12. Income per capita.

The synthetic index allowed for classification of rural areas in a non-accidental linear hierarchy. The foundation for groups were ranges of the index based on the sum of arithmetic average and standard deviation. The following division into 6 classes was made:

- 0.68 and above - rural areas with the highest standard of living,

- 0.67 to 0.34 - rural areas with high standard of living,

- 0.33 to 0.00 - rural areas with relatively high standard of living,

- 0.00 to -0.33 - rural areas with average standard of living,

- -0.34 to -0.67 - rural areas with low standard of living,

- -0.68 and fewer - rural areas with the lowest standard of living.

The index belongs to the group of multidimensional comparative analysis and allows for finding regularities in mutual relations of elements. It facilitates analysing of spatial diversification in development of objects with multiple attributes. It is transparent and has low data loss during data aggregation.

The literature on the subject provides a lot of definitions of the standard of living. The standard of living refers to a degree, to which material and spiritual needs are fulfilled [3]. Definitions and descriptions can be found in the studies written by, among others, Knox [4], Cutter [5], Johansson [6]. For instance, Fontinelle [7] states, that the standards of living can be evaluated by means of comfort, wealth, material assets and the availability of life-necessary means. For the researcher, the most important factors are: income, employment possibilities, availability and quality of health service, costs of services, economic and political stability, and security.

It is worth mentioning that a number of studies have been carried out in the study area for various purposes (i.e., [8], [9], [10], [11]).

\section{RESULTS}

In 2013 there were 6 groups of rural areas with diversified standards of living (Figure 1). Gminas with the highest standards of living amounted to 3.1 per cent (70 locations) out of 2,257 units from study. In this group the synthetic index exceeded 0.68 . The first clusters were composed mainly of areas located near the largest urban agglomerations in voivodeships (NUTS 2 regions): Dolnośląskie, Mazowieckie, Pomorskie and Wielkopolskie. Mazowieckie Voivodeship is the best in attracting and concentrating all development factors - financial, human or social capital, which guarantees their effective use.

The second group was composed of gminas with very good standards of living and Perkal's index ranging from 0.67 to 0.34 . It was 7.8 per cent (175) of rural gminas. These areas were usually located in northern and central-western Poland, and scattered around capitals of the voivodeships: Dolnośląskie, Łódzkie, Mazowieckie, Podlaskie and 
Wielkopolskie. The largest single dense group of units with good standards of living was located in Pomorskie and partially Zachodniopomorskie Voivodeship. These were areas of high environmental value and developed tourist offer in the summer season. In many cases gminas formed single zones in the vicinity of the largest cities in particular voivodeships, e.g. Kielce, Krakow, Lublin and Rzeszów. It mainly depended on the direction of expansion of residential areas, development of transportation system, infrastructural investment as well as popularity of particular locations.

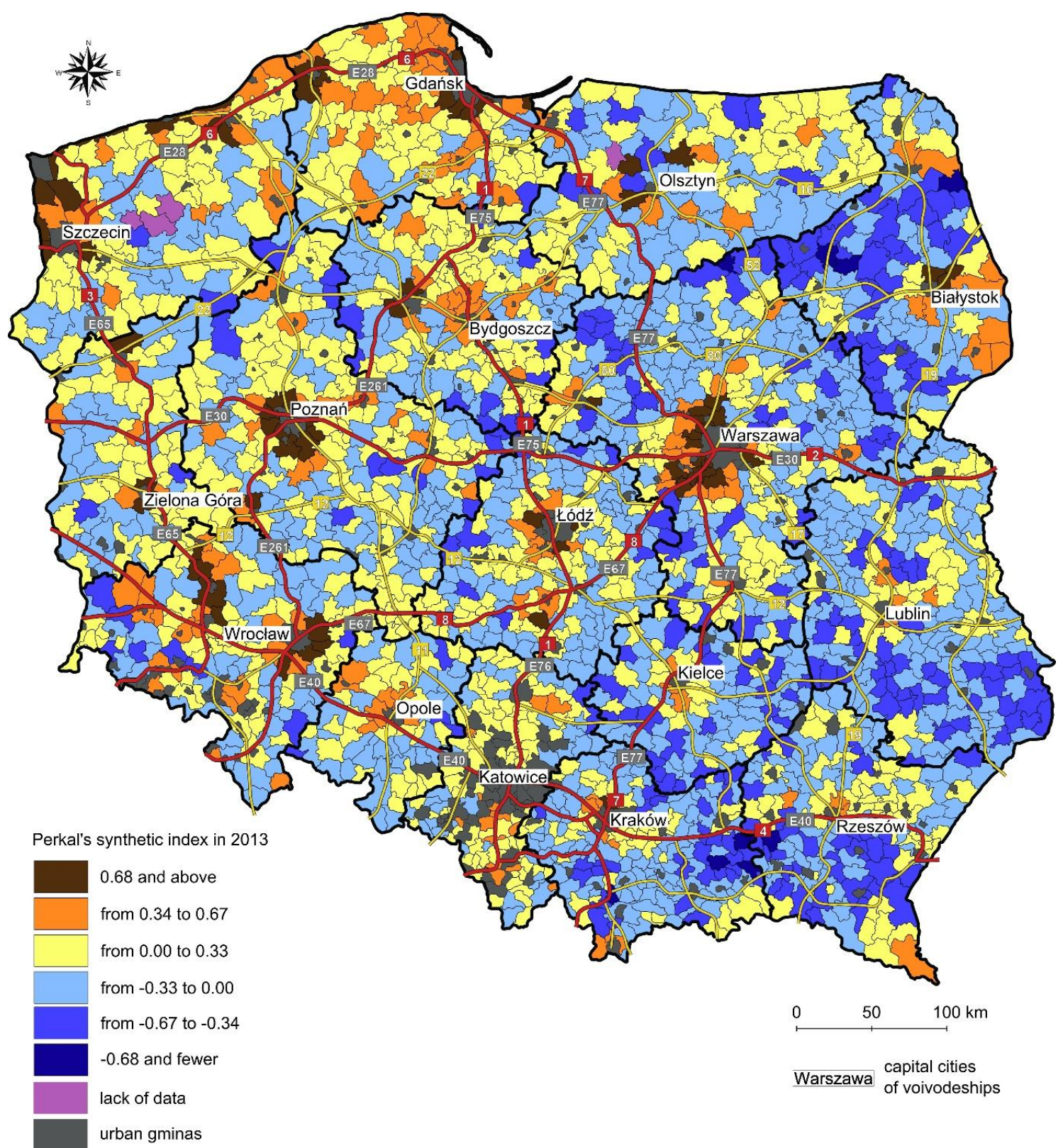

Figure 1. Diversification of the standard of living in rural areas in Poland by the synthetic index in 2013 Source: own elaboration based on data from the Local Data Bank of the Central Statistical Office of Poland.

The third group was composed of territories with the index between 0.33 and 0.00 and they constituted 37.6 per cent (849) of all units in this study. Their standard of living was relatively good and highest density was registered in norther, western and south-western 
part of the country. These territories were very often located in the so-called second ring of suburban zone, in the vicinity of the former (the old administrative system of 49 voivodeships in the period of 1975-1999) and present voivodeship's capital cities. However, in the eastern part of Poland they were mainly scattered, with some exceptions like Lubelskie, Podkarpackie and Świętokrzyskie Voivodeships, where they formed dense groups of rural areas located in the vicinity of the capital's background.

The fourth group was composed of units with the index ranging from 0.00 to -0.33 . It was the largest group comprising 39 per cent (884) of rural gminas. Its standard of living was medium. They dominated in eastern and south-eastern Poland. Their relatively large enclaves were also visible in western and south-western parts of the country.

The fifth group was composed of gminas with the index values between -0.34 and -0.67 . They had low standards of living and amounted to 12 per cent (270) of all analysed areas. Their highest number was registered far from important urban areas, in Eastern Poland. This region was also internally diversified and its development was far behind the rest of Poland. In other research studies it is often classified as so-called problem area, where negative demographic phenomena correspond to economic ones. Their majority is located on mostly agricultural territories, in peripheral areas. A dense group of areas with low standards of living appeared also in Małopolskie Voivodeship.

The lowest standards of living was reported for only 9 gminas constituting 0.4 per cent of all rural areas. The synthetic index was lower than -0.68 . These were singular units with peripheral locations in 4 voivodeships: Małopolskie (4 gminas), Podlaskie (3), Mazowieckie (1) and Podkarpackie (1).

\section{CONCLUSIONS}

The results of the study proves that the standard of living in rural areas in Poland is highly diversified in terms of spatial distribution, which is connected with socio-economic development of those locations. Other factors include industrialization, urbanization of rural areas and activities of urban areas within their voivodeships.

Rural areas with high standard of living are often located along the most important transportation routes, e.g. Warsaw and the arrangement of gminas in southern and western directions with weaker expansion to the east. Another example is Kielce with its expansion in northern and southern directions, along the route Warsaw-Radom-KielceKrakow. Similarly, in Lublin it is linked with the transportation routes towards the capital city. Areas in the vicinity of large cities attract localization of huge investments, because they have: more free space, well developed transport system, lower prices for lots, vicinity of R\&D institutions, large labour market for professionals. Due to their location these areas are 'made for success'. Other conditions follow their favourable locations [12].

Disparities in socio-economic development between particular voivodeships are particularly visible in accumulation of unfavourable development elements in rural areas of eastern and south-eastern Poland. These regions have high percentage of agricultural employment with divided, small-sized farms. Moreover, these areas have to face the problem of migration of young persons as well as depopulation and unbalanced age structure. All these phenomena badly affect possibilities of development and improvement of quality of life in the areas in question.

The standard of living is not a uniform category and its diversification largely depends on the character of a region, its structure, and socio-economic conditions. Characteristic features of rural areas located in the vicinity of urban centres include fast development. 
However, it is based to a great extent on labour resources and potential of a particular zone connected with large cities. Rural areas with economic and often social underdevelopment, with low development dynamics - appear in peripheral locations with respect to the main urban network. They are situated mainly in eastern Poland.

\section{REFERENCES}

[1] Chojnicki Z. Podstawy metodologiczne i teoretyczne geografii, Bogucki Wydawnictwo Naukowe, Poznań, pp. 1-446, 1999.

[2] Runge J. Metody badań w geografii społeczno-ekonomicznej - elementy metodologii, wybrane narzędzia badawcze, Wydawnictwo Uniwersytetu Śląskiego, Katowice, pp. 214-223, 2007.

[3] Liszewski S. Rola i zadania geografii w badaniach zróżnicowania przestrzennego warunków życia mieszkańców miast. Założenia teoretyczne i program badań, In: I. Jażdżewska (Ed.), Zróżnicowanie warunków życia ludności w mieście. XVII Konwersatorium Wiedzy o Mieście, Wydawnictwo Uniwersytetu Łódzkiego, Łódź, pp. 6-17, 2004.

[4] Knox P.L. Level of living: a conceptual framework for monitoring regional variations in wellbeing, Regional Studies, vol. 8, pp. 11-19, 1974.

[5] Cutter S.L. Rating places: A geographers view on quality of live, Resource Publications in Geography, Association of American Geographers, Washington, pp. 1-76, 1985.

[6] Johansson S. Conceptualizing and measuring quality of life for national policy, In: M. R. Hagerty, J. Vogel \& V. Møller (Eds), Assessing quality of life and living conditions to guide national policy, Social Indicators Research Series, Dordrecht, vol. 11, pp. 13-32, 2002.

[7] Fontinelle A. Standard of living vs. quality of life, Investopedia, 2017. (Available at https://www.investopedia.com/articles/financial-theory/08/standard-of-living-quality-oflife.asp)

[8] Korpi T., Nelson K. \& Stenberg S. The accumulation of social problems 1974-2000 (Chapter 4), International Journal of Social Welfare, vol. 16, pp. 91-104, 2007.

[9] Zborowski A. \& Winiarczyk-Raźniak A. Poziom życia w małych miastach obszaru metropolitalnego Krakowa - centrum versus peryferie, Biuletyn Komitetu Przestrzennego Zagospodarowania Kraju Polskiej Akademii Nauk, Warszawa, vol. 232, pp. 147-163, 2007.

[10] Rodríguez-Pose A. \& Tselios V. Individual earnings and educational externalities in the European Union, Regional Studies, vol. 46, pp. 39-57, 2012.

[11] Boncinelli F., Pagnotta G., Riccioli F. \& Casini L. The determinants of quality of life in rural areas from a geographic perspective: the case of Tuscany, Review of Urban and Regional Development Studies, vol. 27, pp. 104-117, 2015.

[12] Bański J. Uwarunkowania sukcesu gospodarczego na wsi, Studia Komitetu Przestrzennego Zagospodarowania Kraju Polskiej Akademii Nauk, Warszawa, vol. 138, pp. 61-76, 2011. 